\title{
American Ginseng: Research Developments, Opportunities, and Challenges
}

\author{
Zamir K. Punja* \\ Department of Biological Sciences, Simon Fraser University, British Columbia V5A 1S6, Canada
}

American ginseng (Panax quinquefolius L.) is grown in some regions of the USA and Canada and marketed for its health promoting attributes. While cultivation of this plant species has taken place in North America for over 100 years, there are many challenges that need to be addressed. In this article, the current production method used by growers is described and the challenges and opportunities for research on this valuable plant are discussed. These include studies on pharmacological activity, genetic diversity within the species, genetic improvement of currently grown plants, molecular characterization of gene expression, and management of diseases affecting plant productivity. The current research developments in these areas are reviewed and areas requiring further work are summarized. Additional research should shed light on the nature of the bioactive compounds and their clinical effects, and the molecular basis of active ingredient biosynthesis, and provide more uniform genetic material as well as improved plant growth, and potentially reduce losses due to pathogens.

Keywords: Panax quinquefolius, Genetic variation, Disease, Transgenic research

\section{INTRODUCTION}

Ginseng (Panax spp.) is a slow-growing perennial herbaceous plant (Order Umbelliferales, Family Araliaceae) that is grown for its highly valued root, which provides a source of vitalizing and stimulating agents $[1,2]$. There are more than six described Panax species, including Panax quinquefolius L. (American ginseng) and Panax ginseng Meyer (Ginseng), which are the two predominant species grown commercially in North America and Asia, respectively [3]. American ginseng is native to eastern North America, and grows as an understory plant in deciduous and mixed forests in regions of the northeastern states of the United States and the Canadian provinces of Quebec and Ontario [2]. Commercial cultivation occurs in Wisconsin, Michigan, North Carolina, Ohio, Tennessee and several other states in the US, while Ontario and British Columbia represent the major grow-

(c) This is an Open Access article distributed under the terms of the Creative Commons Attribution Non-Commercial License (http://creativecommons.org/licenses/by-nc/3.0/) which permits unrestricted non-commercial use, distribution, and reproduction in any medium, provided the original work is properly cited. ing regions in Canada. Cultivation of $P$. quinquefolius in Canada began over $100 \mathrm{yr}$ ago when it became apparent that harvesting of existing wild populations was leading to their extinction. Under commercial cultivation, an average of 3 to $4 \mathrm{yr}$ of growth is required in order for the roots to reach a marketable size. Artificial shade is provided over the crop (Fig. 1A) using a synthetic shade cloth to ensure that only about $30 \%$ of the incident sunlight reaches the plants below (Fig. 1B) to mimic the conditions found in the forest habitat [2]. A layer of straw mulch, consisting primarily of wheat or barley, is placed on the soil surface to reduce damage due to cold weather in the winter and to maintain soil moisture in the summer. During the third and fourth years of growth, the plants produce an umbel-shaped inflorescence (Fig. 1C) and the flowers develop into mature red barriers over the

Received 11 May. 2011, Revised 06 Jul. 2011, Accepted 09 Jul. 2011

*Corresponding author

E-mail: punja@sfu.ca

Tel: +1-778-782-4471, Fax: +1-778-782-3496 

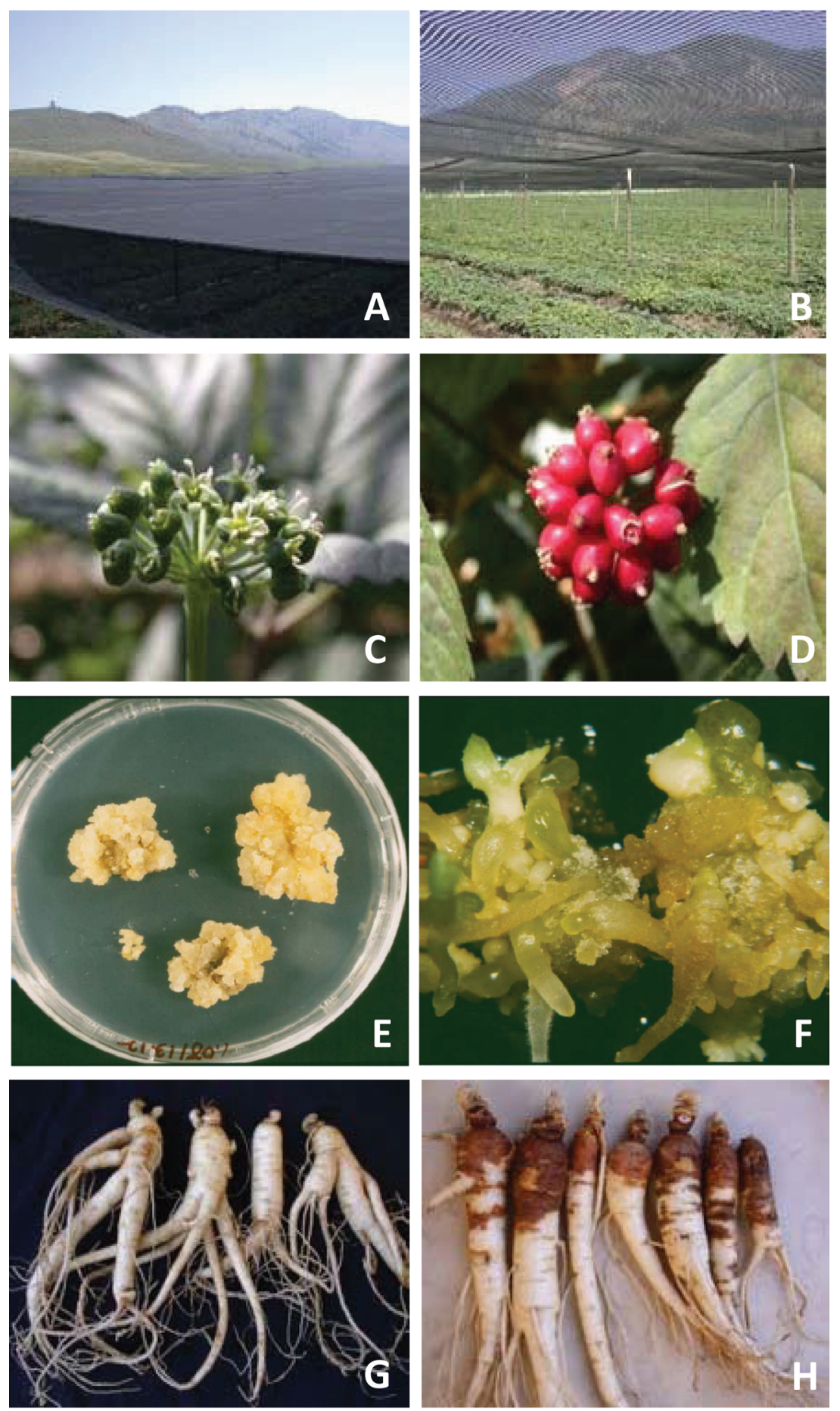

Fig. 1. American ginseng production. (A) Artificial shade cloth used during commercial production. (B) A view of the ginseng plants under the shade cloth. (C) Young developing ginseng inflorescence, showing flowers and green berries. (D) Mature red berries. (E) Tissue culture of ginseng root explant, showing callus development. (F) Somatic embryo and root formation on differentiated ginseng callus. (F) Healthy four-year old American ginseng roots. (G) Roots with extensive reddish-brown discoloration on the crown area due to the rusty root problem.

ensuing 8 to $12 \mathrm{wk}$ period (Fig. 1D). The seeds (ranging from 1 to 3 ) contained inside the berries are used to propagate the next crop after a period of prolonged seed stratification cycle consisting of exposure to cool-warmcool periods over 12 to 18 mo [4]. The commercial production of American ginseng has encountered many challenges but there are also a range of opportunities and developments in research on American ginseng. These are discussed here with an emphasis on improvement of cultivation methods and productivity. 


\section{GINSENOSIDES AND PHARMACOLOGICAL ACTIVITY}

Compared to $P$. ginseng, which has been used as a medicinal plant for centuries and has been studied extensively for its pharmacological activity, the amount of information regarding $P$. quinquefolius is considerably less. However, a recent review by Yuan et al. [5] provides an assessment of the current understanding of the analysis and pharmacological effects of saponins found in P. quinquefolius. In addition, there are other references on this topic $[1,6]$. The roots contain valuable pharmaceuticallyactive components, which include ginsenosides (triterpenoid saponins), polyacetylenes, polyphenolic compounds and acidic polysaccharides. There are differences in the types of ginsenosides present between American and Asian ginseng. At least 30 of the possible 150 known ginsenosides are known to occur in P. quinquefolius. The major ginsenosides are $\mathrm{Rb}_{1}, \mathrm{Rc}, \mathrm{Rd}, \mathrm{Re}, \mathrm{Rg}_{1}$ and $\mathrm{Rb}_{3}$ (accounting for up to $70 \%$ of the total), while $\mathrm{Rf}$ is absent in American ginseng but present in Asian ginseng [5,7,8]. Ginsenoside levels are influenced by root age, and vary in different parts of the plant [8-10]. Highest levels are found in the leaves and root hairs, followed by the root and stem [8]. Ginsenosides levels also differ widely within and between plant populations $[11,12]$. The pharmacological effects, which involve the cardiovascular system, the immune system, the central nervous system as well as anti-cancer and anti-diabetes, are described by Yuan et al. [5] and are not discussed further here.

\section{GENETIC DIVERSITY}

There are currently no identified cultivars of American ginseng but efforts in selection for improved horticultural characteristics have been initiated. This is in contrast to Korean ginseng, where selection of pure lines over many years has led to improved varieties with enhanced growth, root quality and ginsenoside levels [13]. It is reported that cultivation of American ginseng originated from seed or plants collected from the wild, followed by exchange of materials within and between the major production areas. Therefore, plants grown within a commercial field may exhibit considerable phenotypic variability, such as in leaf size and shape, plant height, number of flowers, and root size [14]. This variation can also have an impact on ginsenoside content and levels in roots and eventually in commercial products of American ginseng. This variability could in turn potentially influence the outcome of pharmacological studies and affect the con- sistency of results and therefore remains a challenge to be overcome.

To assess the basis of this genetic diversity, a number of molecular studies have been conducted. Using random amplified polymorphic DNA markers (RAPD), researchers have documented the extent of genetic diversity between cultivated and wild populations of American ginseng, between plants cultivated in different regions of Canada and the US, and between plants growing in a commercial field or originating from the same or different seed lots [14-16]. The findings affirm that American ginseng currently represents a heterogeneous mix of genetic material. The observed genetic diversity in cultivated populations in Canada have resulted largely from a mixing of different seeds lots. In addition, there is a level of heterozygosity within plants that can be maintained through cross-pollination [14]. This type of genetic diversity analysis if conducted on Asian ginseng populations would provide an interesting comparison to assess the extent to which genetic material may differ between different growing regions. The variation seen in American ginseng can be beneficial, however, as it provides a broad base from which to identify vigorous desirable plants for further selection and propagation. The broad-based genetic variation also could confer broader adaptive ability of the ginseng populations to varying biotic or abiotic stresses.

\section{GENETIC IMPROVEMENT}

The long reproductive cycle and difficulties associated with seed germination, and the lack of defined selection criteria, present difficulties in establishing a breeding program for variety development in American ginseng. Not withstanding this, efforts have already begun to identify and select superior plants in research conducted in Canadian laboratories $[17,18]$. As a part of the efforts to initiate genetic improvement of American ginseng, several researchers have previously developed tissue culture methods for regeneration of ginseng plantlets from different explant tissue sources for propagation purposes [1921]. This avoids the need for the prolonged seed stratification and germination phases required for normal seed development and germination. Starting with segments of leaf, or root zygotic embryos, the tissues are induced to produce callus (undifferentiated tissue) (Fig. 1G) on hormone-containing defined tissue culture media [19]. This is followed by a differentiation phase over a 3 to 6 month period in which either somatic embryos or shoots are produced (Fig. 1H). These somatic embryos can also 
be multiplied in large numbers in a liquid suspension culture medium [20]. When rooted, the somatic embryos can give rise to plantlets which then have to undergo an acclimatization phase and be induced to develop a functioning root system [21]. The latter still remains a challenge to the high frequency plantlet recovery that would be required to make tissue culture propagation a practical tool in a breeding program. With further research, the potential still exists for the large-scale clonal propagation of ginseng plants to become a reality. Biochemical and molecular markers can then be used to confirm the genetic identity and stability of the tissue-culture derived plants [20]. Similar tissue culture approaches have also been described for Korean ginseng [22,23].

The ability to regenerate plants in vitro using the above tissue culture methods also provides opportunities for genetic transformation and expression of potentially useful novel genes in ginseng. Methods for genetic transformation have been developed and transgenic plants expressing novel genes have been described for American ginseng $[24,25]$. These have all utilized Agrobacteriummediated gene transfer to achieve the expression of a gene encoding a chitinase protein origination from rice plants, a thaumatin-like protein also from rice, as well as a bacterially-derived gene conferring herbicide resistance $[24,25]$. This approach is still a long way from being utilized in a practical breeding program and the challenge remains as to whether these transgenic plants with foreign genes expressing unique traits would be acceptable for widespread use. This challenge is not unique to ginseng and is encountered in other crop species [26].

\section{MOLECULAR STUDIES}

DNA-based approaches can be used to distinguish between American and Asian ginseng and to establish their relationship to other species of the genus Panax. Both nuclear ribosomal DNA and chloroplast DNA have been examined $[27,28]$. These molecular approaches can also be useful for authentication of products containing fresh or dried roots [29-31]. These techniques can ultimately be used to provide a molecular fingerprint of selected desirable plants or varieties for identification purposes or proprietary protection. DNA markers have not yet been developed which can be used in marker-assisted selection for desired phenotypic traits, such as large root size or high ginsenoside content.

In the context of identifying genes that are expressed in ginseng plants, screening of expressed sequence tags (EST's) from American ginseng root complementary
(cDNA) libraries followed by sequencing of select differentially expressed clones has revealed a large number of genes $(>175)$ with high similarity to those of other plant species found in published databases [32]. These include genes involved in metabolic pathways, cell communication, cellular transport, defense responses, and various other functions [32]. These types of studies are useful to provide a more thorough understanding of the biochemical pathways and gene products present in ginseng which could have a role in its pharmacological activity. Recent studies are identifying through transcript profile analysis putative genes involved in ginsenoside biosynthesis $[33,34]$. This type of research complements earlier studies conducted on Korean ginseng which revealed EST's associated with ginsenoside biosynthesis [35,36]. Proteomic studies have also been conducted with $P$. ginseng but not $P$. quinquefolius.

\section{DISEASE MANAGEMENT}

Undoubtedly the biggest challenge to American ginseng production is the management of diseases which render the ginseng root unmarketable due to infection primarily by fungal pathogens. These micro-organisms infect and damage both the foliage and the roots, causing considerable damage and eventual plant death [37]. The production environment for ginseng, in which thick straw mulch and a shade cloth are used during the summer to simulate a forest canopy environment, provide conditions that are conducive for the survival and multiplication of fungal pathogens. Research has shown that the most prevalent fungal pathogens infecting ginseng include Cylindrocarpon destructans (causing root decay) [38,39], Phytophthora (causing foliar blight and root rot) [37], Alternaria alternata and Botrytis cinerea (causing foliar and seed infection) [37], and Fusarium species and Rhexocercosporidium (causing root infection or rusty root) $[40,41]$. Many of these fungi have the ability to also colonize the developing berries through release of airborne spores and therefore potentially invade the seed [42]. This presents a challenge as the wide dissemination of ginseng seeds has the potential to also spread seedborne pathogens from one region to another. In addition, many seedling-infecting fungi such as Pythium and $\mathrm{Fu}$ sarium species, and Rhizoctonia solani, cause seedling death and reduce plant numbers [43,44]. Molecular techniques have now been developed which allow for the rapid identification of the pathogens infecting ginseng seed $[41,42]$. Growers currently have available only a few disease management options, which include the use 
of fungicides (where registered) or soil amendments to reduce disease severity. Induction of naturally occurring defense responses in the roots through induction of gene expression by elicitors, an approach that has been used in other crops, is an avenue worthy of further investigation in ginseng [45]. Additional approaches to develop environmentally benign methods to emeliorate the impact of fungal pathogens include the use of biological control agents [46] or cover crops/green manure that would promote the establishment of antagonistic soil microflora. However, the perennial nature of ginseng roots presents a challenge with regard to whether these microflora could protect the roots over a 3 to 4 yr period.

A major problem that affects ginseng roots worldwide is the appearance of reddish-brown to orange-brown discolored areas on the root surface, referred to as rusty root or rust spot (Fig. 1H). This significantly reduces the economic value of the roots, in some cases by up to $40 \%$ [47]. The affected tissues display significant biochemical changes, including a build-up of phenolic compounds, accumulation of cations such as $\mathrm{Fe}, \mathrm{Mg}, \mathrm{Si}$ and $\mathrm{Mg}$, as well as an increase in defense-related enzymes [47]. It was postulated that infection by fungal pathogens leads to the induction of these responses in the root. Rusty root remains a challenge in most ginseng production areas, and more research is required to understand the epidemiology of the fungi reported to induce these symptoms and their management.

\section{FUTURE AVENUES FOR RESEARCH}

There are many opportunities for additional research on American ginseng that can provide a better understanding of the genetic and biochemical basis for it's reported health-promoting activities. As a step toward ensuring a more uniform end-product for use by consumers, more consistent levels of ginsenosides and other active metabolites need be achieved through cultivar development. There is sufficient variation currently present to allow for selection to be successful. The availability of specific DNA markers linked to phenotypic traits of interest would be valuable to assist with the selection and improvement of desired attributes. Advancements in molecular breeding and biotechnology which have been developed for many agricultural crops have not yet been utilized for ginseng. Furthermore, research on gene expression and gene regulation can provide useful information on the roles of specific proteins/enzymes that may be involved in the pharmacological activity of American ginseng and how these metabolites could be regulated.
There has been some progress in the utility of transcript profile analysis to elucidate the expression of genes in ginseng tissues and additional work would shed light on the specific genes involved in the complex biochemical pathways likely present in ginseng roots. The availability of transgenic technologies for ginseng would also allow for transgene expression analysis. On the applied side, research on ginseng pathogens and their management should be an on-going priority to avoid losses due to these diseases. Non-chemical approaches have not yet been researched sufficiently to warrant widespread use by growers. This could ultimately provide an opportunity to reduce reliance on fungicides. In addition, there may be opportunities to expand on the current American ginseng products by investigating niche opportunities that may include American 'red' ginseng or organicallygrown ginseng in the future. Finally, the pharmacological activities of the American ginseng root components (saponins as well as other compounds) should be actively researched and compared in clinical studies to the Asian ginseng.

\section{CONCLUSION}

American ginseng has not been researched as extensively as $P$. ginseng at the present time but there are many opportunities to better understand and utilize this species for its health-promoting properties. Areas of research include, but are not limited to, cultivar development, molecular and genetic studies of bioactive compounds, improved production practices and disease management, and clinical studies on pharmacological effects compared to Asian ginseng.

\section{ACKNOWLEDGEMENTS}

This work was supported by funds from the Natural Sciences and Engineering Research Council of Canada (NSERC), Strategic and Discovery Grants Program, as well as by Chai-Na-Ta Ginseng Corporation, the Associated Ginseng Growers of British Columbia and the Ontario Ginseng Growers Association.

\section{REFERENCES}

1. Christensen LP. Ginsenosides chemistry, biosynthesis, analysis, and potential health effects. Adv Food Nutr Res 2009;55:1-99.

2. Proctor JT, Bailey WG. Ginseng: industry, botany, and culture. In: Janick J. Horticultural reviews. Vol. 9. New 
York: Van Nostrand Reinhold, 1987. p.188-236.

3. Wen J. Species diversity, nomenclature, phylogeny, biogeography, and classification of the ginseng genus (Panax L., Araliaceae). In: Punja ZK, ed. Proceedings of the International Ginseng Workshop: utilization of biotechnological, genetic and cultural approaches for North American and Asian ginseng improvement. Burnaby: Simon Fraser University Press, 2001. p.67-88.

4. Schluter C, Punja ZK. Floral biology and seed production in cultivated North American ginseng (Panax quinquefolius). J Am Soc Hort Sci 2000;125:567-575.

5. Yuan CS, Wang CZ, Wicks SM, Qi LW. Chemical and pharmacological studies of saponins with a focus on American ginseng. J Ginseng Res 2010;34:160-167.

6. Attele AS, Wu JA, Yuan CS. Ginseng pharmacology: multiple constituents and multiple actions. Biochem Pharmacol 1999;58:1685-1693.

7. Li TS. Asian and American ginseng: a review. HortTechnology 1995;5:27-34.

8. Li TS, Mazza, G, Cottrell AC, Gao L. Ginsenosides in roots and leaves of American ginseng. J Agric Food Chem 1996;44:717-720.

9. Court WA, Reynolds LB, Hendel JG. Influence of root age on the concentration of ginsenosides of Amreican ginseng (Panax quinquefolium). Can J Plant Sci 1996;76:853-855.

10. Qu C, Bai Y, Jin X, Wang Y, Zhang K, You J, Zhang H. Study on ginsenosides in different parts and ages of Panax quinquefolius L. Food Chem 2009;115:340-346.

11. Smith RG, Caswell D, Carriere A, Zielke B. Variation in the ginsenoside content of American ginseng, Panax quinquefolius L., roots. Can J Bot 1996;74:1616-1620.

12. Schlag EM, McIntosh MS. Ginsenoside content and variation among and within American ginseng (Panax quinquefolius L.) populations. Phytochemistry 2006;67:15101519.

13. Choi KT, Kwon WS, Lee SS, Lee JH, Lee MG. Development of new varieties of Korean ginseng (Panax ginseng C.A. Meyer). In: Punja ZK, ed. Proceedings of the International Ginseng Workshop: utilization of biotechnological, genetic and cultural approaches for North American and Asian ginseng improvement. Burnaby: Simon Fraser University Press, 2001. p.47-52.

14. Schluter C, Punja ZK. Genetic diversity among natural and cultivated field populations and seed lots of American ginseng (Panax quinquefolius L.) in Canada. Int J Plant Sci 2002;163:427-439.

15. Bai D, Brandle J, Reeleder R. Genetic diversity in North American ginseng (Panax quinquefolius L.) grown in Ontario detected by RAPD analysis. Genome 1997;40:111115 .
16. Boehm CL, Harrison HC, Jung G, Nienhuis J. Organization of American and Asian ginseng germplasm using randomly amplified polymorphic DNA (RAPD) markers. J Am Soc Hort Sci 1999;124:252-256.

17. Brown DC, Zhou S, Bhinu VS, Arnason JT, Mcintyre KL. Development and characterization of North American ginseng (Panax quinquefolius L.) germplasm. In: Yang DC, Kim SK, Oh HI, eds. Advances in ginseng research 2010. Proceedings of the 10th International Symposium on Ginseng. Seoul: Korean Society of Ginseng, 2010. p.644-660.

18. Lui EM, Brown DC. New technologies for ginseng agriculture and product development: perspective of the Ontario Ginseng Innovation and Research Consortium. In: Yang DC, Kim SK, Oh HI, eds. Advances in ginseng research 2010. Proceedings of the 10th International Symposium on Ginseng. Seoul: Korean Society of Ginseng, 2010. p.661-674.

19. Tirajoh A, Kyung TS, Punja ZK. Somatic embryogenesis and plantlet regeneration in American ginseng (Panax quinquefolium L.). In Vitro Cell Dev Biol Plant 1998;34:203-211.

20. Punja ZK, Feeney M, Schluter C, Tautorus T. Multiplication and germination of somatic embryos of American ginseng derived from suspension cultures and biochemical and molecular analyses of plantlets. In Vitro Cell Dev Biol Plant 2004;40:329-338.

21. Brown DC, Amyot L, Rintoul T. Micropropagation of North American ginseng (Panax quinquefolius L.): from the test-tube to the field. In: Punja ZK, ed. Proceedings of the International Ginseng Workshop: utilization of biotechnological, genetic and cultural approaches for North American and Asian ginseng improvement. Burnaby: Simon Fraser University Press, 2001. p.163-178.

22. Choi YE, Yang DC, Yoon ES, Choi KT. High-efficiency plant production via direct somatic single embryogenesis from preplasmolysed cotyledons of Panax ginseng and possible dormancy of somatic embryos. Plant Cell Rep 1999; 18:493-499.

23. Zhou S, Brown DC. High efficiency plant production of North American ginseng via somatic embryogenesis from cotyledon explants. Plant Cell Rep 2006;25:166-173.

24. Chen WP, Punja ZK. Agrobacterium-mediated transformation of American ginseng with a rice chitinase gene. Plant Cell Rep 2002;20:1039-1045.

25. Chen WP, Punja ZK. Introduction and expression of a thaumatin-like protein from rice in American ginseng following Agrobacterium-mediated transformation. J Ginseng Res 2003;27:17-23.

26. Punja ZK. Genetic engineering of plants to enhance resis- 
tance to fungal pathogens: a review of progress and future prospects. Can J Plant Pathol 2001;23:216-235.

27. Choi HK, Wen JA. A phylogenetic analysis of Panax (Araliaceae): integrating evidence of chloroplast DNA and the ITS sequences of nrDNA. Plant Syst Evol 2000;224:109-120.

28. Wen J, Zimmer EA. Phylogeny and biogeography of Panax L. (the ginseng genus, Araliaceae): inferences from ITS sequences of nuclear ribosomal DNA. Mol Phylogen Evol 1996;6:166-177.

29. Ngan F, Shaw P, But P, Wang J. Molecular authentication of Panax species. Phytochemistry 1999;50:787-791.

30. Shaw PC, But PP. Authentication of Panax species and their adulterants by random-primed polymerase chain reaction. Planta Med 1995;61:466-469.

31. Shaw PC, Ha WY, Yau FC, But PP, Wang J. Authentication of Panax ginseng and $P$. quinquefolius by multiplex polymerase chain reaction. In: Punja ZK, ed. Proceedings of the International Ginseng Workshop: utilization of biotechnological, genetic and cultural approaches for North American and Asian ginseng improvement. Burnaby: Simon Fraser University Press, 2001. p.113-118.

32. Goswami RS, Punja ZK. Molecular and biochemical characterization of defense responses in ginseng (Panax quinquefolius) roots challenged with Fusarium equiseti. Physiol Mol Plant Pathol 2008;72:10-20.

33. Wu Q, Song J, Sun Y, Suo F, Li C, Luo H, Liu Y, Li Y, Zhang $\mathrm{X}$, Yao $\mathrm{H}$ et al. Transcript profiles of Panax quinquefolius from flower, leaf and root bring new insights into genes related to ginsenosides biosynthesis and transcriptional regulation. Physiol Plant 2010;138:134-149.

34. Sun C, Li Y, Wu Q, Luo H, Sun Y, Song J, Lui EM, Chen S. De novo sequencing and analysis of the American ginseng root transcriptome using a GS FLX Titanium platform to discover putative genes involved in ginsenoside biosynthesis. BMC Genomics 2010;11:262.

35. Jung JD, Park HW, Hahn Y, Hur CG, In DS, Chung HJ, Liu JR, Choi DW. Discovery of genes for ginsenoside biosynthesis by analysis of ginseng expressed sequence tags. Plant Cell Rep 2003;22:224-230.

36. Choi DW, Jung J, Ha YI, Park HW, In DS, Chung HJ, Liu JR. Analysis of transcripts in methyl jasmonate-treated ginseng hairy roots to identify genes involved in the biosynthesis of ginsenosides and other secondary metabolites. Plant Cell Rep 2005;23:557-566.

37. Punja ZK. Fungal pathogens of American ginseng (Panax quinquefolius) in British Columbia. Can J Plant Pathol 1997;19:301-306.

38. Rahman M, Punja ZK. Factors influencing development of root rot on ginseng caused by Cylindrocarpon destructans. Phytopathology 2005;95:1381-1390.

39. Seifert KA, McMullen CR, Yee D, Reeleder RD, Dobinson KF. Molecular differentiation and detection of ginseng-adapted isolates of the root rot fungus Cylindrocarpon destructans. Phytopathology 2003;93:1533-1542.

40. Punja ZK, Wan A, Goswami RS. Root rot and distortion of ginseng seedling roots caused by Fusarium oxysporum. Can J Plant Pathol 2008;30:565-574.

41. Punja ZK, Wan A, Goswami RS, Verma N, Rahman M, Barasubiye T, Seifert KA, Levesque CA. Diversity of $\mathrm{Fu}$ sarium species associated with discolored ginseng roots in British Columbia. Can J Plant Pathol 2007;29:340-353.

42. Punja ZK, Wan A, Rahman M, Goswami RS, Barasubiye T, Seifert KA, Levesque CA. Growth, population dynamics, and diversity of Fusarium equiseti in ginseng fields. Eur J Plant Pathol 2008;121:173-184.

43. Reeleder RD, Brammal RA. Pathogenicity of Pythium species, Cylindrocarpon destructans, and Rhizoctonia solani to ginseng seedlings in Ontario. Can J Plant Pathol 1994;16:311-316.

44. Reeleder RD, Roy R, Capell, B. Seed and root rots of ginseng (Panax quinquefolius L) caused by Cylindrocarpon destructans and Fusarium spp. J Ginseng Res 2002;26:151-158.

45. Jayaraj J, Rahman M, Wan A, Punja ZK. Enhanced resistance to foliar fungal pathogens in carrot by application of elicitors. Ann Appl Biol 2009;155:71-80.

46. Chatterton S, Jayaraj J, Punja ZK. Colonization of cucumber plants by the biocontrol fungus Clonostachys rosea $f$. catenulata. Biol Control 2008;46:267-278.

47. Rahman M, Punja ZK. Biochemistry of ginseng root tissues affected by rusty root symptoms. Plant Physiol Biochem 2005;43:1103-1114. 